\title{
The Long Processes of Short Interfering RNAs - RNA Interference and Its Implications in Neuronal Cells
}

\author{
Paul Lingor Uwe Michel Mathias Bähr \\ S2-Laboratory, Department of Neurology, Faculty of Medicine, University of Göttingen, Göttingen, Germany
}

Key Words

RNA interference $\cdot$ Gene silencing $\cdot$ Neurons

\begin{abstract}
Reverse genetics has been greatly advanced by the discovery of RNA interference (RNAi). This intracellular RNA-mediated gene silencing pathway is partially conserved from plants to mammals and offers a new powerful tool for the analysis of gene function. We give a brief overview of the discovery of RNAi, the underlying mechanisms and probable intrinsic roles of the pathway. Recent reports utilizing RNAi for gene silencing approaches in neuronal cells are reviewed and possible delivery techniques for small interfering RNA/doublestranded RNA are discussed.
\end{abstract}

Copyright (C) 2004 S. Karger AG, Basel

\section{Introduction}

The study of gene function and the elaboration of therapeutic strategies have been boosted by the possibility of investigating gene function in genetically modified organisms. Despite their value, their generation is a laborious task and frequently fails to yield the expected results.

\section{KARGER}

Fax + 41613061234

E-Mail karger@karger.ch www.karger.com
(C) 2004 S. Karger AG, Basel

1660-2854/04/0011-0003\$21.00/0

Accessible online at:

www. karger.com/ndd
Since conventional knock-out or transgenic animals imply the modification of gene function beginning at the embryonic stage, they sometimes fail to survive until adulthood, limiting functional investigations to early developmental stages or making them impossible [1].

Besides genetically modified animals, antisense techniques and ribozymes as well as pharmacological inhibitor approaches have proved useful in the analysis of gene and protein functions. All, however, have limitations due to efficiency, specificity or toxicity. An ideal research tool should thus be able to specifically regulate gene function without overall metabolic or toxic effects and do so at any selected time point. Although such an ideal instrument seems far from being realized, the discovery of RNA interference (RNAi) and microRNAs suggested that cells themselves bear mechanisms fulfilling the above criteria.

\section{Petunias First}

Several years before the term 'RNA interference' was coined, the phenomenon of sequence-specific posttranscriptional gene silencing was observed in plants. In the quest to deepen the pigmentation of petunias, plant biologists introduced a chimeric chalcone synthase gene into the plant's genome, which instead of enhancing the color,
Paul Lingor, MD

Department of Neurology, University of Göttingen

Faculty of Medicine, S2-Laboratory

Waldweg 33, DE-37073 Göttingen (Germany)

Tel. +49 55139 4927, Fax +4955139 14476, E-Mail plingor@gwdg.de 
resulted in more or less pronounced depigmentation [2]. The mechanism underlying this unexpected gene suppression was unclear at that time.

Fire et al. [3] were the first to describe RNAi in the nematode Caenorhabditis elegans as sequence-specific gene silencing in response to double-stranded RNA (dsRNA). dsRNA acted not only in a highly specific manner, but also appeared to be extremely powerful; compared to single-stranded antisense RNA, only a fraction of molecules were required to elicit silencing effects. Several surprising features fascinated the authors; in particular, upon injection of dsRNA, the gene silencing effect was spreading throughout the entire organism and was even propagated to the worm's offspring [3]. Even feeding the worm Escherichia coli expressing dsRNA for endogenous genes resulted in effective gene silencing [4].

\section{Interferon Response - A Mammalian Obstacle}

Next to plants and nematodes, RNAi was soon shown to function successfully in Drosophila [5] and in early mouse embryos and oocytes [6,7]. Thus, there is a large amount of evidence to suggest that the mechanism is evolutionarily conserved. On first sight, RNAi in mammalian cells seemed to contradict a well-known mammalian cellular response mechanism to dsRNA. The so-called interferon response is the mammalian cell's nonspecific answer to long dsRNA and phylogenetically most probably evolved as a safety feature against viral transcripts [8, 9]. Introduction of dsRNA longer than approximately 30 nucleotides into mammalian cells activates PKR, a dsRNA-dependent protein kinase. This leads to inactivation of the translation factor eukaryotic initiation factor $2 \alpha$, which results in a global shutdown of protein synthesis $[10,11]$. Besides PKR activation, long dsRNA also promotes the synthesis of $2^{\prime}, 5^{\prime}$-polyadenylic acid and activation of RNAse L (a sequence non-specific RNAse). Both pathways lead finally to necrosis and/or apoptosis.

Elbashir et al. [12], however, showed that long dsRNA is not essential for the induction of RNAi in mammalian cells. Their experiments revealed that intermediate products of the RNAi mechanism - small dsRNAs of approximately 21-22 nucleotides in length - were able to effectively elicit the same silencing response as did their longer precursors. An induction of the nonspecific interferon pathway was not observed in this case [12]. These findings opened the door to a broader use of small interfering RNAs (siRNAs) for gene silencing in mammalian cells.

\section{The Mechanism of RNAi}

The mechanism of specific mRNA degradation by RNAi is partly understood and key proteins involved in the pathway have been identified. In brief, the process of RNAi can be subdivided into an initiation and effector step, which is followed by an amplification mechanism in some species (fig. 1).

In a first initiation step, long dsRNA is degraded in the cytoplasm by the Dicer enzyme. This well-conserved ribonuclease of the RNAse III family shows substrate specificity for dsRNA and produces small RNA fragments of approximately 22 base pairs. These small dsRNAs are specifically characterized by overhanging 3 '-ends of two nucleotides and phosphorylated 5'-ends. Their function within the RNAi pathway prompted the term 'small interfering' RNAs (siRNAs) [13].

Together with cytoplasmic proteins, the siRNA now forms the RNA-induced silencing complex (RISC), which plays the key role in the effector step of RNAi. The precise composition of RISC is not yet elucidated, but activities of nucleases, a helicase and a homology searching unit have been proposed alongside the siRNA. After ATPdependent unwinding of the double-stranded siRNA, the RISC becomes activated. Within this protein-RNA complex, the antisense strand of the unwound siRNA acts as a guide template; i.e. it targets complementary cytoplasmic mRNA by binding and cleaving it into nonfunctional fragments. This finally leads to inhibition of subsequent protein synthesis [reviewed in ref. 14].

In contrast to antisense mechanisms, RNAi is extremely efficient, requiring only a few molecules per cell in order to initiate specific mRNA degradation. The key to this obvious amplification mechanism - at least in lower eukaryotes - is most likely to be found in the activity of an RNA-directed RNA polymerase (RdRp). Proteins that drive RNA synthesis from an RNA template have been cloned in C. elegans (EGO-1, RRF-1, RRF-3), Arabidopsis (SGS2/SDE1) and Neurospora (QDE-1) [15-17]. It has been suggested that besides playing a direct role in the RISC, siRNAs can also act as primers on the mRNA. $\mathrm{RdRp}$ then synthesizes additional dsRNA, which again is degraded to siRNAs by Dicer. The exact mechanism of this 'random degradative PCR' is so far unknown [18]. However, the amplification mechanism of RNAi likely differs between species. In Drosophila, mouse and human genomes, no RdRp homologues have been identified. Recent evidence suggests that at least in mouse oocytes, RNAi functions without any RdRp activity [19]. Whether this holds true for other higher organisms remains to be 


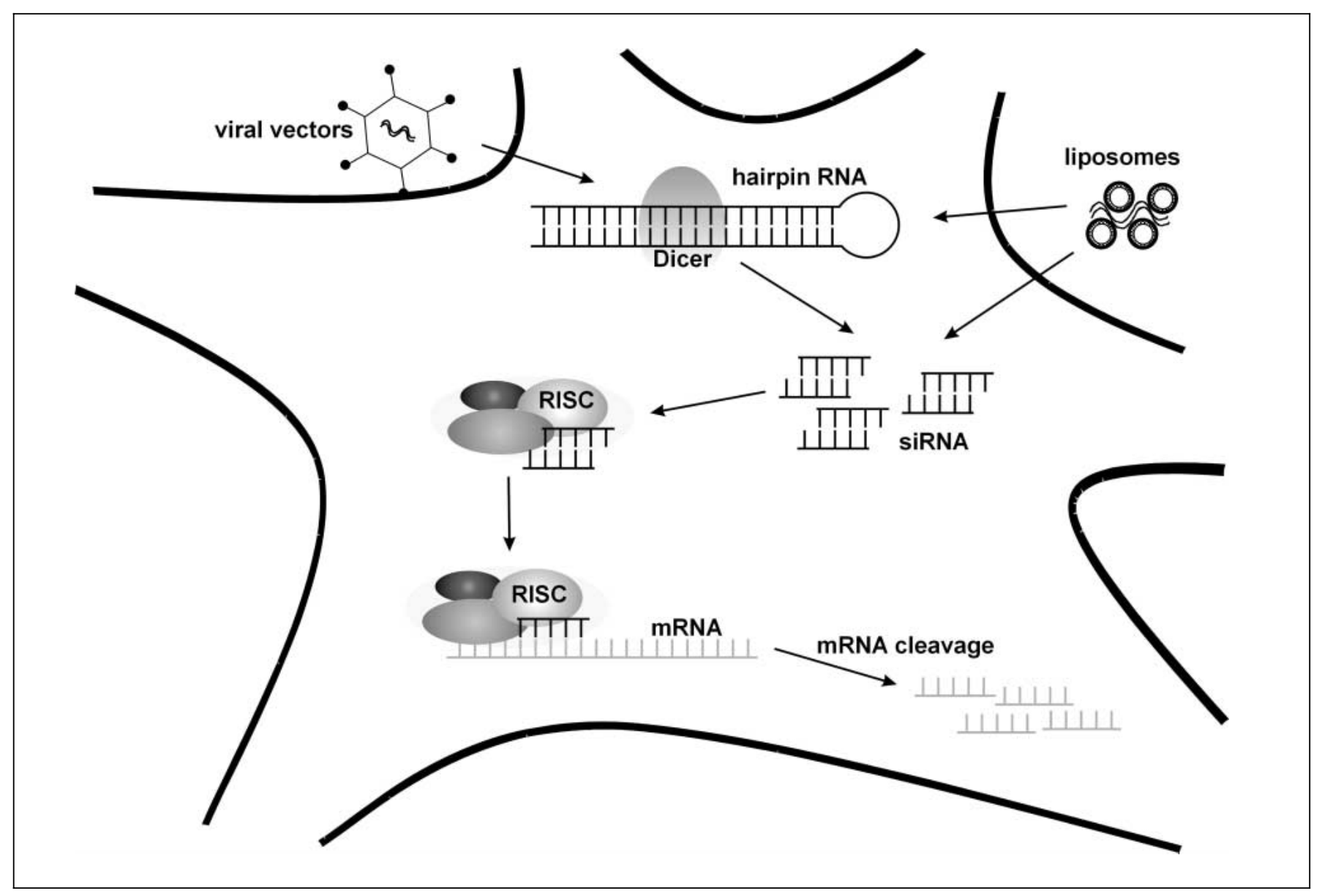

Fig. 1. Approaches of siRNA delivery to neuronal cells and the intracellular RNAi pathway. Recombinant viruses can be used as vehicles for delivery of hairpin RNA expression vectors. Alternatively, RNA expression vectors as well as chemically or enzymatically synthesized siRNA can be applied by lipofection. Hairpin RNA is cleaved by Dicer, producing functional siRNA (initiation step). Intracellularly generated or lipofected siRNA bind to the RISC and target complementary mRNA. Degradation of targeted mRNA is then accomplished by the nuclease activity of RISC (effector step).

elucidated. In species without apparent RdRp activity, an amplification mechanism seems to exist as well and is most likely due to the ability of RISC to destroy more than one target mRNA, acting as catalyst.

\section{Natural Purposes of an RNA-Degrading Pathway}

Besides enabling researchers to knock down gene expression, the RNAi pathway is a mechanism which is conserved throughout different species and most probably serves in gene expression control and defense against viral RNA or mobile genetic elements (transposons) [20].
In plants, a clear role of RNAi in virus defense has been established [21]. Whether this is true for vertebrates remains unclear, but recent experimental evidence showed that siRNAs are able to effectively target and degrade viral RNA of poliovirus in cultured human cells, HIV in primary lymphocytes and Rous sarcoma virus in chick embryos [22-24].

Studies in C. elegans and Arabidopsis suggested that major components of the RNAi pathway, such as the Dicer protein, are required during the development of these organisms [25]. Along with its involvement in the RNAi pathway, Dicer generates small temporal RNAs which then act to inhibit intrinsic mRNA translation [26]. Meanwhile, some 100 so-called microRNAs have been 
Table 1. Examples of gene function analyses in neuronal cells using RNAi

\begin{tabular}{|c|c|c|}
\hline Species/model system & Targeted gene(s) & Report \\
\hline \multicolumn{3}{|l|}{ Caenorhabditis elegans } \\
\hline Adult, in vivo & mec-4, unc-8 & Tavernarakis et al. [29], 2000 \\
\hline Adult, in vivo & mps- 1 , kvs- 1 & Bianchi et al. [45], 2003 \\
\hline Adult, in vivo & $\begin{array}{l}\text { aspartyl proteases asp-1, }-2,-3,-4,-5,-6 \text {, } \\
\text { calreticulin, calpain proteases clp-1, } \\
-3,-4,-6,-7 \text { and tra-3 }\end{array}$ & Syntichaki et al. [30], 2002 \\
\hline Adult, in vivo & $\gamma$-tubulin & Bobinnec et al. [46], 2000 \\
\hline \multicolumn{3}{|l|}{ Lymnaea stagnalis } \\
\hline Adult, in vivo & nNOS & Korneev et al. [47], 2002 \\
\hline \multicolumn{3}{|l|}{ Hirudo medicinalis } \\
\hline \multicolumn{3}{|l|}{ Drosophila melanogaster } \\
\hline S2 cells & $\begin{array}{l}\text { tyrosine kinases DAck, Src42A, Src64, } \\
\text { Shark, Tec29, Abl, phosphatases } \\
\text { DLAR, DPTP61F, DPTP10D, } \\
\text { DPTP69D, corkscrew }\end{array}$ & Muda et al. [49], 2002 \\
\hline Embryo & DPTP52F & Schindelholz et al. [50], 2001 \\
\hline \multicolumn{3}{|l|}{ Mus musculus } \\
\hline P19 cells (differentiated) & neuronal $\beta$-tubulin & Yu et al. [31], 2002 \\
\hline Primary cerebellar granule cells & mDial & Arakawa et al. [33], 2003 \\
\hline AGYNB010 cells (neuroblastoma) & PARP & Gan et al. [51], 2002 \\
\hline Embryo, E10, neural tube & EGFP & Calegari et al. [37], 2002 \\
\hline Neuro2A cells (neuroblastoma) & ABCA1 & Fukumoto et al. [52], 2002 \\
\hline Adult, in vivo & agouti-related peptide & Makimura et al. [53], 2002 \\
\hline \multicolumn{3}{|l|}{ Rattus norvegicus } \\
\hline Primary hippocampal neurons & MAP2 & Krichevsky and Kosik [32], 2002 \\
\hline Primary cerebellar granule cells & $\begin{array}{l}\text { myocyte enhancer factor } 2 \mathrm{~A}, \text { NeuroD } \\
\text { (transcription factor) }\end{array}$ & Gaudillière et al. [54], 2002 \\
\hline
\end{tabular}

identified. Lin-4 and let-7 were the first genes encoding for microRNAs cloned from $C$. elegans, with let-7 having counterparts in humans and other species [27, 28].

\section{RNAi as a Tool for Reverse Genetics in Neuronal Cells}

Currently, RNAi is employed to target almost the entire genome of the model organism C. elegans, including neuronal genes. Initial studies showed that RNAi functions in the worm's neurons, even though it appeared less effective in this subpopulation compared to other cell types. Efficiency of gene silencing depended on the application technique employed, vector-induced dsRNA being more effective than injection of chemically synthesized dsRNA in this model [29, 30]. Similar results were achieved in mouse P19 cells, an embryonic carcinoma cell line, where hairpin siRNAs were more effective than in vitro synthesized siRNA duplexes [31]. Gene silencing by siRNA has recently been demonstrated in primary neurons of mice and rats $[32,33]$. The authors pointed out, however, that cytotoxicity and transfection efficiency in primary mammalian neurons limits applications $[32,33]$. Besides, neuronal cells have been successfully targeted in snails, leeches, fruit flies and some other species (for recent examples, see table 1).

A key question, therefore, remains to be answered before RNAi can become a truly widespread and easy to use biological technique for experimental or even therapeutic gene knock-down: How can interfering RNA be delivered to cells and tissues in an effective and nontoxic manner? This question gains special importance when neuronal cells or the central nervous system (CNS) of vertebrates become targets of gene silencing approaches. 
Similarly to other nucleic acids, dsRNAs or siRNAs can be introduced in vitro using conventional transfection methods. Transfection by cationic liposomes has been one of the most commonly used techniques in RNAi studies. In cell lines, this method provides sufficient transfection efficiency with an acceptable level of toxicity. However, primary cells, notably primary neurons, are much more susceptible to liposome toxicity, and transfection efficiencies are usually too low for functional analyses [32]. Other in vitro techniques include electroporation, calcium phosphate precipitation or microinjection, all of which likewise share detrimental properties.

In vivo dsRNAs or siRNAs effectively mediate RNAi after plain application without any transfection reagents. Gene silencing in C. elegans, for example, has been observed after soaking the worm in dsRNA solution [34]. In mice, injection of siRNA into the tail vein conferred protection in a model of autoimmune hepatitis [35]. Systemic delivery to the CNS, however, is likely to be restricted by the existence of the blood-brain barrier, which prevents the passage of various substances [36]. Studies on mouse and chick embryos successfully employed in vivo electroporation techniques for siRNA delivery [37, 38].

Besides the direct application of siRNA produced by chemical synthesis or in vitro transcription, siRNAs can also be transcribed from expression vectors. The two strands of the siRNA can either be expressed by two separate promoters or by one single promoter expressing a stem-loop RNA [39, 40]. The loop folds back on itself, giving rise to a short dsRNA which then is processed into siRNA by Dicer [31]. Hairpin RNA has been shown to be effectively expressed by viral vectors, such as lentivirus, baculovirus or adenovirus [41-43].

Since viral vector systems have been widely used for transduction of neuronal cells in vivo and in vitro [44], these new siRNA expression approaches might offer a promising tool for gene silencing in neurons.

\section{Future Directions}

The use of RNAi in gene regulation studies is rapidly increasing, underlining the future importance of this technique. Even though some aspects of how RNAi functions differ between species, it has been shown to be effective from nematodes to mammals. Furthermore, several recent studies suggested that RNAi is a valuable tool in neuronal cell lines and even primary neuron cultures. Whether RNAi proves successful in the CNS will be substantially determined by the effectiveness of delivery techniques. The use of viral vector systems seems promising, but will inherit virus-specific handicaps, such as vector toxicity and limited regulation possibilities. Vector-less delivery techniques for the CNS are mostly hampered by their low transfection efficiency. Thus, both technologies might prove useful depending on the experimental setup and will require further optimization. In summary, RNAi is becoming a valuable tool for the examination of gene function to a previously unknown extent. The elucidation of the molecular pathogenesis of diseases, including neurodegenerative or neuroimmunological disorders, is likely to gain major insights from this technique within the next few years.

\section{Acknowledgment}

The authors would like to thank S. Kügler for discussion and comments on the manuscript.

\section{Note Added in Proof}

In contrast to initial results, two recently published articles demonstrate that activation of the interferon response by hairpin RNA expressing vectors or siRNAs may occur in mammalian cells $[55,56]$. Although the effect seems to be dose-dependent and is only elicited by some siRNAs and hairpin RNA expressing vectors, a possible interferon activation has to be considered when interpreting results of RNAi-induced gene silencing.

\section{References}

1 Gao X, Kemper A, Popko B: Advanced transgenic and gene-targeting approaches. Neurochem Res 1999;24:1181-1188.

2 Napoli C, Lemieux C, Jorgensen R: Introduction of a chimeric chalcone synthase gene into petunia results in reversible co-suppression of homologous genes in trans. Plant Cell 1990;2: 279-289.

- 3 Fire A, Xu S, Montgomery MK, Kostas SA, Driver SE, Mello CC: Potent and specific genetic interference by double-stranded RNA in Caenorhabditis elegans. Nature 1998;391:806811.
4 Timmons L, Fire A: Specific interference by ingested dsRNA. Nature 1998;395:854.

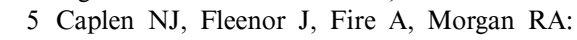
dsRNA-mediated gene silencing in cultured Drosophila cells: A tissue culture model for the analysis of RNA interference. Gene 2000;252: 95-105.

6 Wianny F, Zernicka-Goetz M: Specific interference with gene function by double-stranded RNA in early mouse development. Nat Cell Biol 2000;2:70-75.
7 Svoboda P, Stein P, Hayashi H, Schultz RM: Selective reduction of dormant maternal mRNAs in mouse oocytes by RNA interference. Development 2000;127:4147-4156.

8 Clemens MJ, Elia A: The double-stranded RNA-dependent protein kinase PKR: Structure and function. J Interferon Cytokine Res 1997;17:503-524

9 Stark GR, Kerr IM, Williams BR, Silverman RH, Schreiber RD: How cells respond to interferons. Annu Rev Biochem 1998;67:227-264. 
10 Gil J, Esteban M: Induction of apoptosis by the dsRNA-dependent protein kinase (PKR): Mechanism of action. Apoptosis 2000;5:107114.

11 Manche L, Green SR, Schmedt C, Mathews MB: Interactions between double-stranded RNA regulators and the protein kinase DAI Mol Cell Biol 1992;12:5238-5248.

12 Elbashir SM, Harborth J, Lendeckel W, Yalcin A, Weber K, Tuschl T: Duplexes of 21-nucleotide RNAs mediate RNA interference in cultured mammalian cells. Nature 2001;411:494498.

13 Zamore PD, Tuschl T, Sharp PA, Bartel DP: RNAi: Double-stranded RNA directs the ATPdependent cleavage of mRNA at 21 to 23 nucleotide intervals. Cell 2000;101:25-33.

14 Hannon GJ: RNA interference. Nature 2002; 418:244-251.

$\checkmark 15$ Smardon A, Spoerke JM, Stacey SC, Klein ME, Mackin N, Maine EM: EGO-1 is related to RNA-directed RNA polymerase and functions in germ-line development and RNA interference in C. elegans. Curr Biol 2000;10:169178.

$\checkmark 16$ Dalmay T, Hamilton A, Rudd S, Angell S, Baulcombe DC: An RNA-dependent RNA polymerase gene in Arabidopsis is required for posttranscriptional gene silencing mediated by a transgene but not by a virus. Cell 2000;101: 543-553.

$\checkmark 17$ Cogoni C, Macino G: Gene silencing in Neurospora crassa requires a protein homologous to RNA-dependent RNA polymerase. Nature 1999;399:166-169.

-18 Lipardi C, Wei Q, Paterson BM: RNAi as random degradative PCR: siRNA primers convert mRNA into dsRNAs that are degraded to generate new siRNAs. Cell 2001;107:297-307.

19 Stein P, Svoboda P, Anger M, Schultz RM: RNAi: Mammalian oocytes do it without RNA-dependent RNA polymerase. RNA 2003; 9:187-192.

$\checkmark 20$ Ketting RF, Haverkamp TH, van Luenen HG, Plasterk RH: Mut-7 of C. elegans, required for transposon silencing and RNA interference, is a homolog of Werner syndrome helicase and RNaseD. Cell 1999;99:133-141.

-21 Kasschau KD, Carrington JC: A counterdefensive strategy of plant viruses: Suppression of posttranscriptional gene silencing. Cell 1998; 95:461-470.

-22 Gitlin L, Karelsky S, Andino R: Short interfering RNA confers intracellular antiviral immunity in human cells. Nature 2002;418:430 434.

23 Jacque JM, Triques K, Stevenson M: Modulation of HIV-1 replication by RNA interference. Nature 2002;418:435-538.

-24 Hu WY, Myers CP, Kilzer JM, Pfaff SL, Bushman FD: Inhibition of retroviral pathogenesis by RNA interference. Curr Biol 2002;12:13011311.

-25 Ketting RF, Fischer SE, Bernstein E, Sijen T, Hannon GJ, Plasterk RH: Dicer functions in RNA interference and in synthesis of small RNA involved in developmental timing in $C$. elegans. Genes Dev 2001;15:2654-2659.
26 Grishok A, Pasquinelli AE, Conte D, Li N, Parrish S, Ha I, Baillie DL, Fire A, Ruvkun G, Mello CC: Genes and mechanisms related to RNA interference regulate expression of the small temporal RNAs that control C. elegans developmental timing. Cell 2001;106:23-34.

27 Moss EG: MicroRNAs: Hidden in the genome. Curr Biol 2002;12:R138-R140.

28 Michel U: Non-coding ribonucleic acids - A class of their own? Int Rev Cytol 2002;218: 143-219.

29 Tavernarakis N, Wang SL, Dorovkov M, Ryazanov A, Driscoll M: Heritable and inducible genetic interference by double-stranded RNA encoded by transgenes. Nat Genet 2000;24: 180-183.

30 Syntichaki P, Xu K, Driscoll M, Tavernarakis $\mathrm{N}$ : Specific aspartyl and calpain proteases are required for neurodegeneration in $C$. elegans. Nature 2002;419:939-944.

31 Yu JY, DeRuiter SL, Turner DL: RNA interference by expression of short-interfering RNAs and hairpin RNAs in mammalian cells. Proc Natl Acad Sci USA 2002;99:6047-6052.

-32 Krichevsky AM, Kosik KS: RNAi functions in cultured mammalian neurons. Proc Natl Acad Sci USA 2002;99:11926-11929.

33 Arakawa Y, Bito H, Furuyashiki T, Tsuji T, Takemoto-Kimura S, Kimura K, Nozaki K, Hashimoto N, Narumiya S: Control of axon elongation via an SDF-1alpha/Rho/mDia pathway in cultured cerebellar granule neurons. $\mathrm{J}$ Cell Biol 2003;161:381-391.

34 Tabara H, Grishok A, Mello CC: RNAi in $C$. elegans: Soaking in the genome sequence. Science 1998;282:430-431.

35 Song E, Lee SK, Wang J, Ince N, Ouyang N, Min J, Chen J, Shankar P, Lieberman J: RNA interference targeting Fas protects mice from fulminant hepatitis. Nat Med 2003;9:347-351.

36 Mayhan WG: Regulation of blood-brain barrier permeability. Microcirculation 2001;8:89-104.

37 Calegari F, Haubensak W, Yang D, Huttner WB, Buchholz F: Tissue-specific RNA interference in postimplantation mouse embryos with endoribonuclease-prepared short interfering RNA. Proc Natl Acad Sci USA 2002;99: 14236-14240.

38 Pekarik V, Bourikas D, Miglino N, Joset P, Preiswerk S, Stoeckli ET: Screening for gene function in chicken embryo using RNAi and electroporation. Nat Biotechnol 2003;21:9396.

39 Brummelkamp TR, Bernards R, Agami R: A system for stable expression of short interfering RNAs in mammalian cells. Science 2002;296: 550-553.

40 Paul CP, Good PD, Winer I, Engelke DR: Effective expression of small interfering RNA in human cells. Nat Biotechnol 2002;20:505508.

41 Rubinson DA, Dillon CP, Kwiatkowski AV, Sievers C, Yang L, Kopinja J, Zhang M, McManus MT, Gertler FB, Scott ML, Van Parijs L: A lentivirus-based system to functionally silence genes in primary mammalian cells, stem cells and transgenic mice by RNA interference. Nat Genet 2003;33:401-406
42 Valdes VJ, Sampieri A, Sepulveda J, Vaca L: Using dsRNA to prevent viral infections in vitro and in vivo by recombinant baculoviruses. J Biol Chem 2003;278:19317-19324.

43 Shen C, Buck AK, Liu X, Winkler M, Reske $\mathrm{SN}$ : Gene silencing by adenovirus-delivered siRNA. FEBS Lett 2003;539:111-114.

44 Berry M, Barrett L, Seymour L, Baird A, Logan A: Gene therapy for central nervous system repair. Curr Opin Mol Ther 2001;3:338-349.

45 Bianchi L, Kwok SM, Driscoll M, Sesti F: A potassium channel-MiRP complex controls neurosensory function in Caenorhabditis elegans. J Biol Chem 2003;278:12415-12424.

46 Bobinnec Y, Fukuda M, Nishida E: Identification and characterization of Caenorhabditis elegans gamma-tubulin in dividing cells and differentiated tissues. J Cell Sci 2000;113:37473759.

47 Korneev SA, Kemenes I, Straub V, Staras K, Korneeva EI, Kemenes G, Benjamin PR, O'Shea M: Suppression of nitric oxide (NO)dependent behavior by double-stranded RNAmediated silencing of a neuronal NO synthase gene. J Neurosci 2002;22:RC227.

48 Biswas SC, Dutt A, Baker MW, Macagno ER: Association of LAR-like receptor protein tyrosine phosphatases with an enabled homolog in Hirudo medicinalis. Mol Cell Neurosci 2002; 21:657-670.

49 Muda M, Worby CA, Simonson-Leff N, Clemens JC, Dixon JE: Use of double-stranded RNA-mediated interference to determine the substrates of protein tyrosine kinases and phosphatases. Biochem J 2002;366:73-77.

50 Schindelholz B, Knirr M, Warrior R, Zinn K: Regulation of CNS and motor axon guidance in Drosophila by the receptor tyrosine phosphatase DPTP52F. Development 2001;128:43714382.

51 Gan L, Anton KE, Masterson BA, Vincent VA, Ye S, Gonzalez-Zulueta M: Specific interference with gene expression and gene function mediated by long dsRNA in neural cells. J Neurosci Methods 2002;121:151-157.

52 Fukumoto H, Deng A, Irizarry MC, Fitzgerald ML, Rebeck GW: Induction of the cholesterol transporter ABCA1 in central nervous system cells by liver $\mathrm{X}$ receptor agonists increases secreted Abeta levels. J Biol Chem 2002;277: 48508-48513.

53 Makimura H, Mizuno TM, Mastaitis JW, Agami R, Mobbs CV: Reducing hypothalamic AGRP by RNA interference increases metabolic rate and decreases body weight without influencing food intake. BMC Neurosci 2002;3:18.

54 Gaudilliere B, Shi Y, Bonni A: RNA interference reveals a requirement for myocyte enhancer factor $2 \mathrm{~A}$ in activity-dependent neuronal survival. J Biol Chem 2002;277:4644246446.

55 Bridge AJ, Pebernard S, Ducraux A, Nicoulaz AL, Iggo R: Induction of an interferon response by RNAi vectors in mammalian cells. Nat Genet 2003;34:263-264.

56 Sledz CA, Holko M, de Veer MJ, Silverman RH, Williams BR: Activation of the interferon system by short-interfering RNAs. Nat Cell Biol 2003;5:834-839. 